\title{
21st Century Sports Management
}

\author{
Nugroho Susanto $^{1 *}$ and Zulbahri ${ }^{2}$ \\ ${ }^{1,2}$ Faculty of Sport Science, Universitas Negeri Padang, Padang, Indonesia \\ *Corresponding author. Email: nugrohosusanto@fik.unp.ac.id
}

\begin{abstract}
In the $21^{\text {st }}$ century, Sports management is the science and experience for all mankind, in their performances, profession or society that involve the output, stimulation, publicity or classification of any physical exercise associated to an interest or product. Sports institutional management consists of personal sports management, programs, marketing, information, infrastructure advice, and human resources. Sports management has quite unique aspects. These aspects are sports marketing, the financial structure of a sports company, the career path of the sports industry, and sport as a social institution. The new 21 st century management paradigm that places sports as an industry or business can be divided into a number of parts, namely: sports as the entertainment industry, sports as a service industry and sports as a driver for the development of the goods industry. three approaches to defining the nature and field of the sports industry are by making industrial models that show the interrelationships between segments / parts of the sports craft. The three models are output variety model, economic effect model, and sports performance model
\end{abstract}

Keywords: Management, Sports, Industry

\section{INTRODUCTION}

Management in sports provides sports maturation, common design operations in the sport areas, the process of implementing human resource development policies, and deciding to implement the most appropriate solution. Sports government and commerce, is one of the most significant. Marketing agents in sports today are not only bound in discussions, publicity, and underwriting, but also present many assistances. Some guiding constituents for achievement and competitive benefit both in government, commerce and sports; and commonly felicitous, having and governing information. Sports management as an unstructured skill for the experience of talented managers from athletes, teams that emerge with the appearance of professional sports organizations. Sports management is related to the development of the professionalization of physical exercise.

Sports activities can be grouped into three important parts, namely: educational sports, recreational sports and achievement sports [1]. Sports education is a sport activity that is used to achieve educational goals, namely the inculcation of sports values and awareness about doing sports activities for the health and freshness of the body. Recreational sports are sports activities that aim to get pleasure, satisfaction and can refresh their physical and spiritual fitness. While sports achievement is a sport activity that aims to achieve high achievements in the sports that are carried out.
Sports management as a fast developing sphere of learnings, qualifications and abilities. A considerable section of individual resources who are interested in sports is to consider it another profession. From the orientation of management activities to differentiate to perform the functions of the sports process, to holistic supervision, where all angles of governing sports as a profession must be installed in every day operational occupation that frequently occur in a sum of sports equipments. From a perspective of supervision, sport reflects an evolutionary part of fashionable human life. The organizational structure in sports management is based on procedures, constitutions, conceptual, and interstate and worldly principles.

\section{DISCUSSION}

Managing sports organizations in the early $21 \mathrm{st}$ century involves the application of techniques and strategies. Sports administrators are involved in necessary design, conduct great amounts of individual resources, achieving the prosperity of professional sportsman and sponsors. Sports managers need to develop an understanding of sports management and industry.

Sports management is a divided chapter in sports discipline [2]. The basic requirements of science are having their investigation fields and using measurable procedure in managing objects of action. From a supervision perspective, sport characterizes a 
part of fashionable human life that aims to, establish and enhance the biologic and emotive aspects of implementers and participants in sports activities.

Sports management has developed very rapidly in the 21st century. The ordinary extension of the worldwide sports industry, the exploitation economic of sporting programs and contests, incorporated with the familiarization of paid personnel into voluntary government organizations and more and more people now making a living by managing sports or sports organizations, have forcing sports organizations and their managers to become more professional. With the development of sports (sports education, recreation, achievement, kinesiology, etc.), sport has become a discipline of its own as management has become a discipline of its own and is widely studied in universities. Therefore, management disciplines that are related to sports disciplines have formed a new interdiscipline called sports management. As such, sports management has become one of the fields of science that many sports experts or practitioners are in.

Establishes sports management as an academical science that employs designing, incorporating, influencing, ruling, bargaining, guiding, and assessing expertise in an association or station in a sport-related profession. So, sports management is about applying sport management theory in the profession [3].

21 st century sports management develops the brand identity of each sponsor to maximize income potential through strategic marketing. Sports management is the science and experience for all mankind, in their performances, profession or society that involve the output, stimulation, publicity or classification of any physical exercise associated to an interest or product [4].

Sports management directs an institution that focuses on competitive sports. Clarification of the duty of leaders in sports management will allow the investigation of styles to uplift organizations using existing supplies [5]. The chief has executed obligation for changing cooperative relationships within institutions as evidenced by the relationship between all personal beliefs.

Management in this case is broadly covers all matters related to sports. The scope includes sports clubs, sports organizers, field facilities (building), sports equipment, supporting facilities such as inns / hotels, as well as parties involved such as athletes, coaches, managers, and even spectators.

Sports management is the science and experience for all mankind, in their performances, profession or society that involve the output, stimulation, publicity or classification of any physical exercise associated to an interest or product. Sports management in a broad sense is associated with various types of sports associated with careers. Sports management also has quite unique aspects. These aspects are: 1) sports marketing, 2) financial structure of sports companies, 3) sports industry career paths, and 4) sports as a social institution.

Sports management in the 21 st century can theoretically be explained as a fusion of expertise interrelated to designing, incorporating, harmonizing, encouraging and guiding in organizations or departments related to sports. As a fast growing business, sports management employs human resources, produces economic activities and processes so as to influence the determination of the quality of people's lives [6].

The 21 st century is now a period marked by the emergence of globalization. The phenomenon of globalization is a new era of human civilization where there is a very rapid change in various fields of life. Technology and science are developing very rapidly, supported by the process of information transformation in such a way that it causes changes in the pattern of human life. The era of globalization was originally a manifestation of changes and developments in information systems, telecommunications and transportation with the phenomenon that can shorten the distance in relations between countries or between regions within the boundaries of space and time.

The world in the era of globalization becomes as if without limits, which is marked by the emergence of free trade (free trade) between global economic actors. The implication is that market conditions are becoming increasingly competitive, high customer demands, especially those related to product quality and logistics accuracy, fulfillment of patents, environmental factors, and product innovations that must have a tendency to increase.

The era of free markets in the 21st century is a period of open trade competition both in the form of goods and services at the international level. Whereas in the field of sports, the competition is characterized by the increasing flexibility of the trainers and business players of sports facilities / equipment that enter Indonesia which cannot be prevented through discriminatory treatment and regulations by the Indonesian government.

Efforts to build the world of Indonesian sport is by as much as possible to get the sympathy and participation of the entire community. Therefore, we need a way to improve and place sport as an integral part of people's lives and become pride. The way is to make sports as an industry, both the goods industry and the service industry. 
Industry is the activity of a group of people in a system to produce a product that will be used by another group of people as part of their daily needs. For example, an activity by a group of people in a shoe factory, or a shoe craftsman, is an industry that produces shoes that are needed by other groups of people as part of their daily needs.

This also applies to sports, in order to produce something useful, the supporting factors that need to be taken into account, namely: 1) sports are part of the necessities of life, demand and supply for the whole community; 2) sport becomes an activity of a group of people to produce something that is needed by the market community or users; 3) sports require human resources, raw materials, land, facilities, science and technology, management, funds, systems and networks; 4) sports, if desired to be competitive must be proactive, innovative, creative, and have a touch of art in accordance with the tastes and interests of the market and supported by excellent quality control; 5) sports if desired to be advanced and large must be supported by the introduction of market needs, promotion and advertising, as well as services and approaches to customer satisfaction; 6) sports if desired to be sustainable must be managed professionally and seriously.

There are three approaches to defining the nature and nature of the sports industry by creating industrial models that show the interrelationships between segments / parts of the sports venture. The three models are output variety model, economic effect model, and sports performance model. The sportgenerating field in this model is the essence of the business, and six assisting subsectors that encircle yonder, and complement the core operation producers. One of the organizations in the subsector is an organization that provides products and services for the core organization or sells / trades products related to sports.

Based on necessary scheme is a process of maturing and an action to examine the assignment of sports organizations, overall goals, general strategies and allocation of resources. The results of the review carried out that in 21 st century sports management which consists of planning phases in sports are revised as follows: (1) planning phase, (2) strategy formulation phase, (3) implementation strategy, and (4) evaluation and control of planned tasks [7].

Sports management in the 21 st century, the authors conclude that a plan for managing sports organizations in the early $21 \mathrm{st}$ century binds the employment of certified systems and procedures in most existing interests, legislature and volunteer institutions. Sports administrators are involved in necessary design, conduct great amounts of individual resources, dealing with multibillion-dollar broadcasting contracts, managing the welfare of elite athletes. Therefore practitioners especially in the field of sports science need to develop an understanding of sports and industry.

The world of sports today is developing very fast. This expansion is not only reflected in the prelude of various fresh sports, but as well as in the multiplying collection of chances to cooperate in activities and sports, an increase in the number and variety of magazines linked to sports, as well as sites about sports on the internet, increasing mass media that expose activities sports, increasing numbers and categories of sports plant and competitions, and increasing concern in touring and escapade sports trips.

To encourage sports management researchers to consider developing theories. In developing sports management theory, it is better to consider the environment. This is adjusted to developments in the 21st century today [8].

Asserts that adopting a sociological approach and a critical reflexive approach can enable sports management by practitioners and scholars to begin to understand better about how social issues are closely embedded in management, governance, marketing, and sports development [9]. 21st century sports management is a new way of organizing and managing sports, as well as researching and teaching in the field of sports management.

When new professional sports have emerged, the sports opportunities offered to various populations are more, support and sponsorships are increasing, the education of the sports industry is appropriate for extended equitable and advanced, commerce and improvement orientations are developing in the sports business, sports administrators are reasonable for enhanced qualification, and rapid progress in the Modernization of the sports business. Of course, this increase will increase job opportunities for those who aspire to become sports managers

\section{CONCLUSION}

Sports management in the 21st century must be run seriously, because the development of technology and science will cause a lot of competition. Sports in this century can be used as a promising industry or business, because of globalization which is characterized by the free market.

Making sport one of the industries of the future is very promising, all of which depend on each individual. Can we prepare all of it to further strengthen the position of sport as an industrial strength. The way is by developing human resources as executors in the field. The quality and competence of human resources who 
handle sports must be empowered to support the coaching and development of sports, both at the regional and national levels, both for achievement sports or for community sports.

\section{REFERENCES}

[1] Kemenegpora. (2005). Undang-undang RI Nomor 3, Tahun 2005, tentang Sistem Keolahragaan Nasional.

[2] Vasile M, dan Sorin Dacian B (2013) Sports Organizations Management and Science. Procediasocial and behavior sciences 117

[3] Laird Curt, 2005, The Influence of Sport Management Program Characteristics on Academician Perceptions Of NASPE-NASSM Approval, Smart Online Journal, Volume I, Issue II, 2005.

[4] Pedersen, P. M., et al. (Eds.). (2011). Contemporary Sport Management, 4th ed. Champaign, IL: Human Kinetics.
[5] Imbroda-Ortiz et al. 2015. Sports Management, Leadership in the Organization. Journal of Physical Education and Sports Management December 2015, Vol. 2, No. 2, pp. 56-65

[6] Darshana Rani. 2016. Sports Management and Opportunities for Professional Development. Journal of Sports and Physical Education. Volume 3 , Issue 4

[7] Radovan. 2013. Strategic planning at sports organizations. Journal of Process Management. Vol. 1, No.4, 2013.

[8] Janet S, 2011. Theory development in sport management: My experience and Other considerations, Jurnal, Sport Management Review Vol 16.

[9] Knoper, A. 2015. Assessing the sociology of sport: on critical sociology and sport management, internasional Review for the sociology of sport, 50 . 496-501 